\title{
Impact of Propylene Glycol on some Nutritional, Chemical and Technological
} Properties of Dairy Zaraibi Goats

El-Sawah, T. H. ; G. E. El-Emam² ; A. M. Abdel-Gawad ${ }^{3}$ and E. I. Khalifa ${ }^{3}$

${ }^{1}$ Milk Technology Research Department, Animal Production Research Institute, Dokki, Giza, Egypt.

${ }^{2}$ By-products Utilization Research Department, Animal Production Research Institute, Dokki, Giza, Egypt.

${ }^{3}$ Sheep and Goats Research Department, Animal Production Research Institute, Dokki, Giza,

Egypt.

Corresponding author: xyezz@yahoo.com

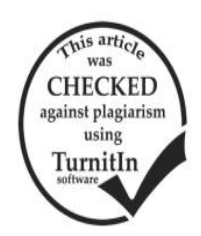

\begin{abstract}
To evaluate the effects of propylene glycol (PG as powder) on some nutrition parameters (digestion coefficient and nutritive values) and some productive parameters (milk yield and composition) and its effects on the quality of milk processing for Domiatti cheese). An experiment was conducted by eighteen lactating Zaraibi goats in $3^{\text {rd }}$ lactation season with an average body weight of $36 \pm 5.46 \mathrm{Kg}$ and aged 39 months. In this experiment, three treatments were employed as six does in each treatment. The treatments done up to 21 weeks during lactation season and included: (1) control without PG (PG0), (2) 10g PG /doe/day (PG1) and (3) 20 g PG/doe/day. All treated goats were received basal ration contained 50\% concentrate feed mixture (CFM) $+50 \%$ roughage (as berseem hay and rice straws) through lactation period up to 21 weeks. Apparent digestibility of CP, TDN and DCP was affected $(\mathrm{P}<0.05)$ by PG administration. Acetate and propionate were increased by using PG, but level of butyrate has increase significant for PG0. Moreover, the results could be showed that milk yield and milk compositions were affected $(\mathrm{P}<0.05)$ by the PG addition compared to control. Also, increasing PG levels from 10 to $20 \mathrm{~g}$ /does/day did not have any significant effect on milk yield, milk composition and other nutrition parameters. The cheese sample yield was slightly decreased particularly within PG1 and PG2 compared to PG0 cheese. The total solids and titratable acidity were slightly increased and $\mathrm{pH}$ values were slightly decreased by using PG milk. The PG cheese samples had significant $(\mathrm{P}<0.05)$ differences in TN/DM\%, FA/DM\% during the ripening period. The cheese made from PG1 and PG2 had the higher $(\mathrm{P}<0.05)$ score points for organoleptic properties than PG0 after continually storage period for 60 days. The results indicate that PG is an appropriate alternative for goats to prevent energy deficiency in the lactation period, while increasing the daily PG dose from 10 to $20 \mathrm{~g}$ has no significant but observed beneficial effect.
\end{abstract}

Keywords: Nutrition parameters, milk yield, milk composition and manufacturing Domiatti cheese, dairy goats.

\section{INTRODUCTION}

The use of alternative nutrients is important in the composition of feedstuffs because they help to reduce production costs. In this context, the biofuels industry has increased the availability of propylene glycol (PG), which may become an increasingly important material for concentrate feedstuffs for livestock (Lien et al., 2010).

Thus, the same authors defined that PG is rich in energy (4.7 Mcal NE/L), rapidly absorbed and in the rumen approximately $80-90 \%$ usually metabolized $3 \mathrm{~h}$ after feeding. It may be used to reduce the negative energy balance after calving and limiting the risk of ketosis and fatty liver. Shankare Gowda et al. (2013) revealed that PG is metabolized in the rumen to lactic acid and propionic acid, which are converted to glucose by hepatocytes which absorbed by the rumen wall or from the gastrointestinal tract and is converted to glucose by the liver. Furthermore, Cruz et al. (2014) refers to a successful use of PG that reduced plasma concentrations of free fatty acids, urea and increased plasma concentrations of glucose, insulin, cholesterol and Insulin- growth factor 1 (IGF-I). Recently, Nalawade et al. (2015) mention that PG has been the most carefully studied glucogenic supplement, that may has antibacterial and antifungal effects. Also those authors claimed that PG had bactericidal effects on many bacteria, especially E. coli. In general, PG is a substance used to prevent negative energy balance (NEB) in pre-parturient and prevention ketosis (Azza et al., 2015). The PG could be increased the energy in the late phase of pregnancy and reduction levels of metabolites used for interpretation of energy balance such as beta-hydroxybutyric acid (BHBA) and non-esterified fatty acid (NEFA) concentrations (Mecitoğlu et al., 2017). It also optimized the metabolic parameters in pre and post-partum periods of sheep which have no negative effects on the suckling lambs (Santos et al., 2017). On the other hand, Akamatsu et al. (2018) suggests that PG prevents liver dysfunction related to an insufficiency of bile excretion occurs in cows with ketosis.

In this sense, the objective of this article was to assess the effect of PG supplementation on nutrition parameters (as digestion coefficient and nutritive values) and productive parameters (as milk yield, milk composition and milk manufacturing as domiatti cheese) of dairy Zaraibi goats.

\section{MATERIALS AND METHODS}

Study area

This experimental study was carried out at El-Serw Research Station, Damietta government which belonging to Animal Production Research Institute (APRI), Agriculture Research Center, Ministry of Agriculture, Egypt. The experimental period lasted from June to October 2018.

Experimental animals

A total number of 18 dairy Zaraibi goats in $3^{\text {rd }}$ lactation season were appeared healthy and clinically free of diseases diagnosed at the time of study. The average live body weight of goats was $36 \pm 5.46 \mathrm{~kg}$ and aged 39 months. Three experimental goats' groups were used to evaluate the effect of supplementation $0.0,10$ or $20 \mathrm{~g}$ of PG to basal ration offered to dairy goats during 21 weeks of lactation season.

\section{Experimental diets}

The dairy goats were randomly allotted to three groups with six does in each group. The goats in the $1^{\text {st }}$ group served as a control (PG0) without any addition 
of PG. They were received basal herd ration routinely practiced in the farm. The PG0 group was fed 50\% CFM $(1000 \mathrm{~g} / \mathrm{h} / \mathrm{d})+50 \%$ roughage included $800 \mathrm{~g} / \mathrm{h} / \mathrm{d}$ as berseem hay (BH) and $200 \mathrm{~g} / \mathrm{h} / \mathrm{d}$ rice straws (RS).

However, propylene glycol (PG) was added to basal ration herd in the $2^{\text {nd }}$ group (PG1) and $3^{\text {rd }}$ group (PG2) at 10 and $20 \mathrm{~g} / \mathrm{h} / \mathrm{d}$, respectively. All goats were received PG0, PG1 and PG2 rations twice daily, one part at 9 a.m and other part at 4 p.m. Each experimental group was fed individually and its feedstuff provided to the goats to achieve the milk production needs according to National Research Council recommendations (NRC, 2007). Also, the fresh water and mineral blocks were available as free choice all trial period.

The chemical compositions of the forming essential ingredients (as CFM, BH and RS) were analyzed according to AOAC (2007) as shown in Tables 1. In addition, data in Table 2 explained that calculation of fiber fraction and feeding values of basal ingredients ration as the Neutral Detergent Fiber (NDF), Acid Detergent Fiber (ADF) and Acid Detergent Lignin (ADL) that determined for essential ingredients according to the methods of Van Soest et al. (1991). Also, hemicellulose was calculated as $\mathrm{NDF}$ - ADF, cellulose as ADF - ADL (Rinne et al., 1997), total digestible nutrients $(\mathrm{TDN})=129.39-0.9419(\mathrm{CF}+$ NFE), digestible crude protein $(\mathrm{DCP})=0.9596(\mathrm{CP})-3.55$, digestible energy $(\mathrm{DE})=0.04409(\mathrm{TDN} \%)$, metabolizable energy $(\mathrm{ME})=1.01(\mathrm{DE})-0.45$ and net energy $(\mathrm{NE})=$ 0.0245 (TDN \%) - 0.12 according to NRC (2007).

Table 1. Chemical analysis of forming essential ingredients according to dry matter base.

\begin{tabular}{lccc}
\hline \multirow{2}{*}{\begin{tabular}{c} 
\%emical analysis \\
\cline { 2 - 4 }
\end{tabular}} & \multicolumn{3}{c}{ Experimental rations (\% as DM) } \\
\cline { 2 - 4 } OM & CFM & BH & RS \\
\hline CP & 87.77 & 87.65 & 78.33 \\
CF & 14.42 & 13.15 & 2.94 \\
EE & 10.07 & 30.91 & 35.82 \\
NFE & 2.42 & 2.33 & 2.24 \\
Ash & 60.86 & 41.26 & 37.33 \\
\hline
\end{tabular}

Table 2. Chemical analysis of forming essential ingredients according to dry matter base.

\begin{tabular}{|c|c|c|c|}
\hline \multirow{2}{*}{$\begin{array}{l}\text { Chemical analysis } \\
\%\end{array}$} & \multicolumn{3}{|c|}{ Fiber fraction \% of DM } \\
\hline & CFM & BH & RS \\
\hline $\mathrm{NDF}$ & 42.95 & 55.88 & 69.48 \\
\hline $\mathrm{ADF}$ & 17.29 & 43.29 & 43.95 \\
\hline ADL & 5.79 & 36.96 & 35.85 \\
\hline Hemicelluloses & 25.66 & 12.59 & 25.53 \\
\hline Celluloses & 11.50 & 6.33 & 8.10 \\
\hline \multicolumn{4}{|c|}{ Feeding values \% of DM } \\
\hline TDN & 62.75 & 61.41 & 60.49 \\
\hline DCP & 10.29 & 9.07 & -1.35 \\
\hline DE (M cal/kg DM) & 2.76 & 2.71 & 2.67 \\
\hline ME (M cal/kg DM) & 2.34 & 2.29 & 2.25 \\
\hline $\mathrm{NE}$ (M cal/kg DM) & 1.42 & 1.38 & 1.36 \\
\hline
\end{tabular}

Nutrition parameters

During an experimental feeding period (postweaning up to 21 weeks of lactation season), digestibility trials were conducted to determine nutrients digestion coefficient and rumen liquor of the experimental rations.

Three does from PG0, PG1 and PG2 groups were chosen to determine digestibility coefficients and rumen liquor parameters of the experimental rations.

\section{Digestibility coefficients}

Feces samples were taken from the rectum of each doe twice daily at 12 hours as an interval during the collection period (5 days). Representative samples of the tested feedstuffs were taken as well as samples of feces.

Each day's fecal output of each group was weighed and $20 \%$ was sub-sampled and stored frozen at $-20^{\circ} \mathrm{C}$. The daily total fecal excretion per group was used for the determination of digestibility coefficient. Then, samples of feces were dried at $55^{\circ} \mathrm{C}$ for about $72 \mathrm{hrs}$ in a forced draft oven and ground to pass $1 \mathrm{~mm}$ mesh screen size and used for determination of chemical composition according to AOAC (2007). Neutral detergent fibers (NDF) and acid detergent fiber (ADF) were analyzed based on the method of Van Soest and Robertson (1985).

\section{Rumen liquor}

During the digestibility trials, rumen liquor was obtained via rubber stomach tube using gentle mouth suction. Rumen liquor was sampled before feeding (0 hour) and at 3 and 6 hours after feeding. The samples were filtered through two layers of surgical gauze. Immediately post- rumen liquor collected, the values of ruminal $\mathrm{pH}$ were determined using a $\mathrm{pH}$ meter. Then, $1.0 \mathrm{ml}$ of saturated $\mathrm{HgCl}_{2}$ solution was added to inhibit microbial fermentation. After acidification of rumen liquor samples using concentrated orthophosphoric acid and $0.1 \mathrm{~N}$ hydrochloric acid, concentration of volatile fatty acids (VFA's) was determined by steam distillation methods as described by Warner (1964). However, determination of $\mathrm{NH}_{3}-\mathrm{N}$ concentration was carried out according to Conway and O'Malley (1957).

\section{Volatile fatty acid (VFA's)}

During the digestibility trials, samples of rumen liquor were collected for VFA's analysis using $1.0 \mathrm{ml}$ extracted from the flasks at $12 \mathrm{~h}$ of incubation and conserved with $4 \mathrm{ml}$ of $25 \%$ metaphosphoric acid. Samples were centrifuged at $2500 \times \mathrm{g}$ for $20 \mathrm{~min}$. The supernatant was obtained and aliquots were taken for VFA analysis by gas chromatography (Erwin et al., 1961).

\section{Milk yield}

Post-weaning (at 90 days), the commercial milk amount was recorded weekly up to 21 weeks of lactation season. The hand is used within 12 hours as interval periods between morning and evening lactation. At the day of evaluated milk value, the morning milk harvest from each goat / trial group was cooled at $5^{\circ} \mathrm{C}$ and added to the evening cooled milk which well mixed as one amount.

Then, this amount of milk obtained was multiplied in 7 days to give milk harvest weekly.

Milk composition

The composition of commercial milk was evaluated at 21 weeks of lactation period. The milk samples were taken up to $200 \mathrm{ml}$ / goat during the previous periods. The $200 \mathrm{ml}$ of milk samples were analyzed included $100 \mathrm{ml} /$ doe from cooling morning milk plus $100 \mathrm{ml} /$ doe/ from cooling evening milk which had well mixed as one sample.

The milk samples were analyzed for total solids (TS), fat (FA), solids not fat (SNF) and lactose by using digital Lactoscans, Milk analyzer, Wide LCD 8900 Nova Zagora, Bulgaria. 
Some characteristics of manufacturing domiatti cheese

Goat's milk of different treatments was heated to $40^{\circ} \mathrm{C}$. Salt was added to all treatments at $12 \%$ and finally milk was renneted. After complete coagulation, the resultant curds were ladled in wooden frames, lined with muslin cloth. After 24 hours, the resultant cheese of all treatments were weighed and pickled into their own whey. The cheese samples were stored in plastic jars at $25^{\circ} \mathrm{C}$ for 2 months.

Samples of cheese were analyzed. The organoleptically and cheese samples analyzed after 0,30 and 60 days of ripening period using three replicates of each treatment. The organoleptically was conducted as following: 15 points for appearance, 35 points for body and texture and 50 points were given for flavor. While, cheese sample were analyzed for total solids (TS), fat/dry matter (FA/DM), TN/DM as the methods described by (Ling, 1963) and (A.O.A.C., 2007), $\mathrm{pH}$ was measured by using a digital $\mathrm{pH}$ meter by direct immersing the glass electrode in cheese sample. Cheese yield was confined according to the formulation which reported by Metzger et al. (2000). Cheese sensory was evaluated according to Nelson and Trout (1965).

\section{Statistical Analysis}

Data were explored for comparison among treatment groups as PG0, PG1 and PG2 rations, sampling were performed using the one-way Repeated Measure Analysis of Variance (ANOVA) that applied to evaluate the influence of the propylene glycol on the considered parameters (as nutrition parameters, milk yield, milk composition and milk manufacturing) using the SPSS/PC computer program (Version 22.0 SPSS, 2013). Differences were considered significant when $p$ values were less than 0.05 using the Duncan post hoc test of SPSS program.

\section{RESULTS AND DISCUSSION}

\section{Chemical composition}

Data presented in Table 3 summarized chemical composition for tested ratios.

Table 3. Chemical analysis of trial rations (\% dry matter basis).

\begin{tabular}{lccc}
\hline Chemical analysis & \multicolumn{3}{c}{ Experimental rations } \\
\cline { 2 - 4 } \% & PG0 & PG1 & PG2 \\
\hline OM & 86.59 & 81.51 & 79.29 \\
CP & 13.66 & 13.45 & 13.35 \\
CF & 25.49 & 24.52 & 23.14 \\
EE & 2.33 & 2.78 & 2.67 \\
NFE & 45.11 & 40.75 & 40.13 \\
Ash & 13.41 & 18.49 & 20.71 \\
\hline & Fiber fraction & \\
NDF & 48.24 & 45.59 & 43.20 \\
ADF & 39.11 & 37.55 & 35.21 \\
ADL & 20.38 & 19.56 & 18.34 \\
Hemicelluloses & 9.13 & 8.04 & 7.99 \\
Celluloses & 18.83 & 17.99 & 16.87 \\
\hline & Feeding values & \\
TDN & 62.89 & 67.91 & 69.80 \\
DCP & 9.56 & 9.36 & 9.26 \\
DE (M cal/kg DM) & 2.77 & 2.99 & 3.08 \\
ME (M cal/kg DM) & 2.35 & 2.57 & 2.66 \\
NE (M cal/kg DM) & 1.42 & 1.54 & 1.59 \\
\hline
\end{tabular}

The chemical analysis of diets showed that contents of EE and ash were higher; while contents of OM and CP were lower in PG1 and PG2 than in PG0 ration. Increasing
OM in PG0 compared to PG1 and PG2 was due to ash content in CFM, BH and RS. However, contents of CF were nearly similar among all rations. In addition, total fat content as measure by ether extract was higher in PG0 than PG1 and PG2 rations due to the lowest fat content in propylene glycol. The current results reported that all experimental rations were isonitrogenous and isocaloric during time of lactation. The calculated chemical composition is in agreement with the chemical composition of experimental rations obtained by Ben Salem et al. (2005) with dairy goats, in early lactating cows (Gowda et al., 2013), in primiparous buffalo (Abdel-Latif et al., 2016), and in sheep (Santos et al., 2017) which supplied with propylene glycol.

\section{Digestibility coefficients}

Digestibility coefficients of PG0, PG1 and PG2 ration indicated that $\mathrm{OM}, \mathrm{CF}, \mathrm{EE}$ and NFE did not significantly ( $\mathrm{P}>0.05$ ) differ among trial rations (Table 4). This response is similar to that obtained by Ben Salem et al. (2005) who indicated that feeding value of diets (OM, $\mathrm{CF}, \mathrm{EE}$ and NFE) was not affected by the amount and the frequency of PG supply. The PG administered daily at a rate of 10 or $20 \mathrm{~g}$ increased crude protein digestibility. From this, Madibela et al. (2006) attributed the high crude protein (CP) digestibility and $\mathrm{NH}_{3}-\mathrm{N}$ concentration to tannin deactivate by PG. Consequently, the improvement of CP digestibility due to PG supplementation in this study is consistent with the report of Gowda et al. (2013). There is confirmation with previous studies by Ben Salem et al. (2005) who reported that crude protein digestibility was 531, 625 and $614 \mathrm{~g} / \mathrm{kg}$ when PG supplemented at $0,10 \mathrm{~g}$ and $20 \mathrm{~g}$ to diet, respectively. Interestingly, Franzolin and Dehority (2010) found that extended periods of low rumen $\mathrm{pH}$ are probably more detrimental to the survival of ciliate protozoa population in the rumen that is a good indicator to increase DCP. On the other hand, Besharati and Taghizadeh (2011) showed that addition of PG to basal diets had an increasing effect on digestibility of crude protein (DCP) by liberate protein from the preformed tannin-protein complexes. Also, these latter authors have noted that the presence of PG could increase microbial plant adhesion and/or the fibrolytic microbial activity. As well as, Al-Masri (2016) suggested that the PG might have bound with tannins; allow to releasing proteins for microbial breakdown, this linked with higher production of microbial nitrogen in the presence of PG. In the current study, the digestibility values of dry matter (DVDM) were significantly $(\mathrm{P}<0.05)$ increased in PG0 compared to PG1 and PG2 ration. This effect was observed in study of Hilton et al. (1986) who clearly that elevation of PG from $0 \%$ to $10 \%$ could increase DVDM from $69.8 \%$ to $71.0 \%$, respectively. Also, Madibela et al. (2006) proved that in vitro dry matter digestibility (IVDMD) using PG was improved. However, the study of Ben Salem et al. (2005) revealed that DVDM was 596, 609 and $597 \mathrm{~g} / \mathrm{kg}$ when PG supplemented at $0,10 \mathrm{~g}$ and $20 \mathrm{~g}$ to diet, respectively.

However, calculation of TDN and DCP during the experimental feeding, showed significant $(\mathrm{P}<0.05)$ greater values in PG1 and PG2 goats than those goats in PG0 group. Hence, the present results indicated significant $(\mathrm{P}<0.05)$ improvement in digestibility coefficients of most nutrients and in nutritive values as TDN and DCP of 
ration, when PG were supplied to ration in particular during feeding with $\mathrm{BH}$ and RS. Thus, these include mainly the use of polyethylene glycol (PG) that releases forage proteins and improves fodder potential of these forages (Santos et al., 2017).

Table 4. Average digestibility coefficients, fiber fraction and feeding values of the experimental rations.

\begin{tabular}{|c|c|c|c|}
\hline \multirow{2}{*}{$\begin{array}{l}\text { Chemical analysis } \\
\%\end{array}$} & \multicolumn{3}{|c|}{ Experimental groups } \\
\hline & PG0 & PG1 & PG2 \\
\hline \multicolumn{4}{|c|}{ Digestibility coefficients (\%) } \\
\hline DM & $68.97^{\mathrm{a}}$ & $64.45^{b}$ & $62.98^{\mathrm{b}}$ \\
\hline $\mathrm{OM}$ & 67.98 & 64.95 & 63.54 \\
\hline $\mathrm{CP}$ & $61.13^{\mathrm{b}}$ & $65.95^{\mathrm{a}}$ & $65.88^{\mathrm{a}}$ \\
\hline $\mathrm{CF}$ & 57.21 & 54.93 & 53.67 \\
\hline $\mathrm{EE}$ & 79.68 & 81.16 & 80.24 \\
\hline NFE & 67.42 & 64.82 & 64.57 \\
\hline \multicolumn{4}{|c|}{ Fiber fraction (\%) } \\
\hline NDF & 51.14 & 49.61 & 48.51 \\
\hline $\mathrm{ADF}$ & 45.25 & 43.95 & 43.98 \\
\hline ADL & 25.49 & 23.89 & 23.55 \\
\hline Hemicellulose & 5.89 & 5.66 & 4.53 \\
\hline Cellulose & 19.76 & 20.06 & 20.43 \\
\hline \multicolumn{4}{|c|}{ Feeding values (\%) } \\
\hline TDN & $12.00^{\mathrm{b}}$ & $16.60^{\mathrm{a}}$ & $18.02^{\mathrm{a}}$ \\
\hline DCP & $55.11^{\mathrm{b}}$ & $59.72^{\mathrm{a}}$ & $59.67^{\mathrm{a}}$ \\
\hline
\end{tabular}
each feeding system are significantly different at $(\mathbf{P}<\mathbf{0 . 0 5})$.

\section{Rumen liquor}

Result in Table 5 revealed that inclusion of PG at both levels in PG1 and PG2 rations of dairy goats during lactation season has significantly $(\mathrm{P}<0.05)$ decreased $\mathrm{pH}$ value and concentration of VFA's but increased ammonia concentration in sampled before or post-feeding. In this context, Alipour and Rouzbehan (2007) reported the greater ruminal ammonia and VFA's concentration caused with more rapid ruminal fermentation when PG was given. The lowest $\mathrm{pH}$ in rumen liquor of goats received PG1 and PG2 ration may be due to great concentration of lactic acid.

The highest $\mathrm{pH}$ produced with PG was similar to those found by Kristensen and Raun (2007) who suggested that PG has effects on metabolism by the following modes of action: (1) supply of glucogenic substrates by increasing absorption of PG as well as propanol, propionate and propanal originating from ruminal metabolism of PG makes PG glucogenic in the classical sense, (2) increased supply of l-lactate and propionate to gluconeogenesis, and (3) insulin resistance of peripheral tissues induced by increased concentrations of PG. From this, Ferraro et al. (2016) found that VFA's increased and ammonia-N decreased in the rumen liquor of sheep received PG orally.

They also noted that PG rapidly diffuse through the rumen wall and is fermented by rumen microbes resulting in VFA's production by the greatest propionate and acetate, but has the lowest butyrate after fermentation. Results from our experiment indicate that PG increased ammonia-N; the fermentation pattern obtained in this study was similar to that reported by Madibela et al. (2006). Based on these results, inclusion of PG adversely affected $\mathrm{pH}$ and VFA's production in rumen liquor. Kristensen and Raun (2007) recorded that $\mathrm{pH}$ was 6.60-6.63, total VFA's reached to 97.0 and $93.0 \mathrm{mM}$ (included acetate $65.1-61.6 \mathrm{~mol} / 100$, propionate 21.5 - $24.9 \mathrm{~mol} / 100$ and butyrate 9.6 $9.1 \mathrm{~mol} / 100$ ) in control and PG fed to Holstein cows, respectively. Regarding to great ruminal $\mathrm{NH}_{3}-\mathrm{N}$ concentration, the increase in the gas production in the presence of $\mathrm{PG}$ is possibly due to an increase in the available nutrients to rumen micro-organisms, especially the available nitrogen. Besharati and Taghizadeh (2011) confirmed that PG caused a significant and marked increase in the rate and extent of ammonia production in the rumen.

Table 5. Effect of feeding PG0, PG1 and PG2 rations on rumen liquor parameters at each of sampling time.

\begin{tabular}{|c|c|c|c|c|}
\hline \multirow{2}{*}{$\begin{array}{l}\text { Rumen liquor } \\
\text { parameters }\end{array}$} & \multirow{2}{*}{$\begin{array}{c}\text { Assay } \\
\text { Time /hours }\end{array}$} & \multicolumn{3}{|c|}{ Experimental rations } \\
\hline & & PGo & PG1 & PG2 \\
\hline \multirow{6}{*}{ Ruminal $\mathrm{pH}$ value } & \multirow[b]{2}{*}{0} & 7.29 & 7.35 & 7.34 \\
\hline & & \pm 0.45 & \pm 0.66 & \pm 0.56 \\
\hline & \multirow[b]{2}{*}{3} & $6.77^{\mathrm{a}}$ & $6.33^{\mathrm{b}}$ & $6.38^{\mathrm{b}}$ \\
\hline & & \pm 0.44 & \pm 0.63 & \pm 0.67 \\
\hline & \multirow{2}{*}{6} & $6.88^{\mathrm{b}}$ & $6.72^{\mathrm{a}}$ & $6.84^{\mathrm{a}}$ \\
\hline & & \pm 0.57 & \pm 0.77 & \pm 0.79 \\
\hline \multirow{6}{*}{$\begin{array}{l}\text { Concentration of } \\
\text { VFA's } \\
\text { (meq/100 ml) }\end{array}$} & \multirow{2}{*}{0} & $11.66^{\mathrm{a}}$ & $9.42^{b}$ & $9.37^{b}$ \\
\hline & & \pm 3.45 & \pm 2.44 & \pm 2.66 \\
\hline & \multirow{2}{*}{3} & $16.57^{\mathrm{a}}$ & $13.78^{b}$ & $13.79^{\mathrm{b}}$ \\
\hline & & \pm 3.58 & \pm 3.25 & \pm 3.55 \\
\hline & \multirow{2}{*}{6} & $14.56^{\mathrm{a}}$ & $10.86^{\mathrm{b}}$ & $10.98^{\mathrm{b}}$ \\
\hline & & \pm 4.55 & \pm 4.66 & \pm 4.56 \\
\hline \multirow{6}{*}{$\begin{array}{l}\text { Ruminal } \mathrm{NH}_{3}-\mathrm{N} \\
\text { concentration } \\
(\mathrm{mg} / 100 \mathrm{ml})\end{array}$} & \multirow{2}{*}{0} & 19.13 & 19.41 & 20.19 \\
\hline & & \pm 5.44 & \pm 4.22 & \pm 6.11 \\
\hline & \multirow{2}{*}{3} & $22.14^{b}$ & $23.87^{\mathrm{a}}$ & $24.58^{\mathrm{a}}$ \\
\hline & & \pm 7.44 & \pm 6.98 & \pm 6.58 \\
\hline & \multirow{2}{*}{6} & $19.58^{b}$ & $21.27^{\mathrm{a}}$ & $21.57^{\mathrm{a}}$ \\
\hline & & \pm 5.88 & \pm 5.98 & \pm 6.45 \\
\hline
\end{tabular}

a and b: Means within the same row within different superscripts for each feeding system are significantly different at $(\mathrm{P}<0.05)$.

Volatile fatty acid (VFA's)

Average of VFA's values included acetate, propionate and butyrate \% of experimental rations computed by goats are shown in Table 6.

Table 6. Effect of feeding PG0, PG1 and PG2 rations on proportions of VFA's produced by ruminal fermentation.

\begin{tabular}{lccc}
\hline \multirow{2}{*}{$\begin{array}{l}\text { Experimental } \\
\text { rations }\end{array}$} & \multicolumn{3}{c}{ Volatile fatty acid (VFA's) \% } \\
\cline { 2 - 4 } PG0 & Acetate & Propionate & Butyrate \\
\hline \multirow{2}{*}{ PG1 } & $55.14^{\mathrm{b}}$ & $24.57^{\mathrm{b}}$ & $20.48^{\mathrm{a}}$ \\
& \pm 2.11 & \pm 2.11 & \pm 1.07 \\
\hline \multirow{2}{*}{ PG2 } & $58.29^{\mathrm{a}}$ & $28.58^{\mathrm{a}}$ & $13.13^{\mathrm{b}}$ \\
& \pm 3.13 & \pm 2.33 & \pm 1.16 \\
\hline
\end{tabular}

a and b: Means within the same column within different superscripts for each feeding system are significantly different at $(\mathrm{P}<0.05)$.

The improvement benefit of the effect of PG supplementation in this study is consistent with some other results (Madibela et al., 2006, Besharati and Taghizadeh, 2011, Pechová et al., 2014 and Ferraro et al., 2016), but contrasts to other report (Kristensen and Raun, 2007) revealed the lowest acetate values in blood plasma flow in hepatic artery $(2.48 \mathrm{mmol} / \mathrm{h})$ in PG cows compared to control cows $(3.01 \mathrm{mmol} / \mathrm{h})$. However, these authors noticed that propionate (131 and $77 \mathrm{mmol} / \mathrm{h}$ ) and butyrate (28 and $41 \mathrm{mmol} / \mathrm{h}$ ) in blood plasma flow in hepatic artery of PG and control cows were in agreement with the present results, respectively. 


\section{Milk yield}

Milk production was recorded weekly up to 21 weeks of lactation for goats which received supplementation of propylene glycol at PG1 and PG2 compared to PG0 as shown in Table 7. Although PG supplementation had no significant effect on milk yield during the experimental period from $7^{\text {th }}$ week to $11^{\text {th }}$ weeks of lactation season; yet, they were superior to PG0. In this context, the results observed in the present study are in agreement with those reported by Formigoni et al. (1996) who found non significant effect of PG supplementation on milk yield during mid carve of lactation. At the beginning week of lactation, it was similar among the treatments as reported by Borş et al. (2014), their results showed no effect on milk yield when PG supplied to diet.

Moreover, Azza et al. (2015) revealed that PG at 100 and $200 \mathrm{ml}$ had no effect on early milk yield then, their averages were 10.12 and $10.36 \mathrm{~kg}$ compared to $11.56 \mathrm{~kg}$ in control dairy cows, respectively. In the current study, a higher milk yield $(\mathrm{P}<0.05)$ was observed for PG1 and PG2 goats from $14^{\text {th }}$ to $21^{\text {st }}$ weeks of lactation. Apparent the advanced to offered PG through lactation season; the milk yield tended to increase $(\mathrm{P}>0.05)$ to reach the highest average amount in PG2 goats compared to those goats treated with PG1 ration. Similarly, Rukkwamsuk and Panneum (2010) did not find significant increase in mean milk yield on PG supplementation in early and mid lactation period but increased in late milking compared to control cows. In this context, Kupczyński et al. (2005) found that milk amount for cows fed PG at $500 \mathrm{ml} / \mathrm{d} / \mathrm{h}$ was 38.63 and $42.85 \mathrm{~kg}$ compared to 35.04 and $42.52 \mathrm{~kg}$ in the period of 3 and 10 first weeks of lactation, respectively.

Similar results were obtained by Gavan and Motorga (2009) who demonstrated that PG is a glucogenic precursor may be justified by potentially higher milk yields thus; average greater milk production was $32.2 \mathrm{~kg} /$ day for cows receiving PG than those receiving the diet without PG (29.2 kg/day) during lactation period. In addition, the current findings are in close conformity with the reports of Lomander et al. (2012) who documented that a significant increase in milk production by PG supplementation in early and late lactating cows. Therefore, there is a suggestion that PG could improve energy status by providing additional gluconeogenic precursor for the hepatic production of glucose which leads to increase milk yield (Rukkwamsuk and Panneum, 2010). Also, Lien et al. (2010) recorded that PG has significantly higher milk yield at $27.27 \mathrm{~kg} / \mathrm{d}$ than $26.63 \mathrm{~kg} / \mathrm{d}$ in control dairy cows. In addition, Gowda et al. (2013) concluded that the supplementation of PG resulted in favorable effect on milk yield; hence average milk yield was reached to 14.52 and $16.01 \mathrm{~kg} /$ day for control and PG cows, respectively.

Furthermore, in a previous work (Hussein et al., 2015), it was stated that there is a positive relationship between energy balance and milk yield, but rather energy balance is a function of both feed intake and milk yield.

Hence, those authors defined that the milk yield was higher in the PG (10.7 kg/day) group than control (8.4kg/day) group; such increase could be attributed to the energy for milk production increased because of PG supplementation. As well as, Mecitoğlu et al. (2017) found that PG caused significantly higher milk yield in 6, 7, 8 weeks (as a late weeks of production), it was 42.52, 43.00 and $44.03 \mathrm{~kg}$ than $38.82,39.72$ and $38.66 \mathrm{~kg}$ in control cows, respectively. Generally, positive effects of PG on milk production are mainly attributed to increases in glycogenic precursors and maintained a moderated metabolic energy status which resulting on bacterial populations that synthesize propionic acid which reflected on milking amount (Melendeza et al., 2018).

Table 7. Effect of feeding PG0, PG1 and PG2 rations on weekly milk yield harvest.

\begin{tabular}{lccc}
\hline Milk yield & \multicolumn{3}{c}{ Experimental rations } \\
\cline { 2 - 4 } weekly & PG0 & PG1 & PG2 \\
\hline W1 & $3.50 \pm 0.18$ & $3.73 \pm 0.17$ & $4.14 \pm 0.28$ \\
W2 & $3.26 \pm 0.19^{\mathrm{b}}$ & $3.97 \pm 0.29^{\mathrm{ab}}$ & $4.55 \pm 0.32^{\mathrm{a}}$ \\
W3 & $2.92 \pm 0.31^{\mathrm{b}}$ & $3.68 \pm 0.32^{\mathrm{ab}}$ & $4.31 \pm 0.25^{\mathrm{a}}$ \\
W4 & $2.69 \pm 0.37$ & $3.43 \pm 0.11$ & $3.44 \pm 0.34$ \\
W5 & $2.68 \pm 0.29^{\mathrm{b}}$ & $3.38 \pm 0.28^{\mathrm{ab}}$ & $3.79 \pm 0.27^{\mathrm{a}}$ \\
W6 & $2.86 \pm 0.31^{\mathrm{b}}$ & $3.38 \pm 0.44^{\mathrm{ab}}$ & $4.18 \pm 0.27^{\mathrm{a}}$ \\
W7 & $2.73 \pm 0.32$ & $2.93 \pm 0.36$ & $3.44 \pm 0.29$ \\
W8 & $2.68 \pm 0.25$ & $3.43 \pm 0.27$ & $3.44 \pm 0.25^{2}$ \\
W9 & $2.86 \pm 0.43$ & $3.13 \pm 0.29$ & $3.73 \pm 0.25^{29}$ \\
W10 & $2.80 \pm 0.44$ & $3.32 \pm 0.29$ & $3.44 \pm 0.26$ \\
W11 & $2.86 \pm 0.46$ & $3.33 \pm 0.23$ & $3.38 \pm 0.27$ \\
W12 & $2.57 \pm 0.41^{\mathrm{b}}$ & $3.27^{\mathrm{a}} \pm 0.26$ & $3.56 \pm 0.12^{\mathrm{a}}$ \\
W13 & $2.39 \pm 0.33^{\mathrm{b}}$ & $3.09 \pm 0.32^{\mathrm{ab}}$ & $3.76 \pm 0.18^{\mathrm{a}}$ \\
W14 & $2.22 \pm 0.26^{\mathrm{b}}$ & $3.09 \pm 0.23^{\mathrm{a}}$ & $3.27 \pm 0.17^{\mathrm{a}}$ \\
W15 & $2.03 \pm 0.24^{\mathrm{b}}$ & $3.19 \pm 0.27^{\mathrm{a}}$ & $3.38 \pm 0.35^{\mathrm{a}}$ \\
W16 & $1.81 \pm 0.21^{\mathrm{b}}$ & $2.69 \pm 0.15^{\mathrm{a}}$ & $3.03 \pm 0.21^{\mathrm{a}}$ \\
W17 & $1.75 \pm 0.34^{\mathrm{b}}$ & $2.68 \pm 0.15^{\mathrm{a}}$ & $2.98 \pm 0.21^{\mathrm{a}}$ \\
W18 & $1.52 \pm .33^{\mathrm{b}}$ & $2.58 \pm 0.25^{\mathrm{a}}$ & $2.86 \pm 0.25^{\mathrm{a}}$ \\
W19 & $1.46 \pm 0.37^{\mathrm{b}}$ & $2.51 \pm 0.32^{\mathrm{a}}$ & $2.92 \pm 0.25^{\mathrm{a}}$ \\
W20 & $1.17 \pm 0.35^{\mathrm{b}}$ & $2.39 \pm 0.22^{\mathrm{a}}$ & $2.57 \pm 0.21^{\mathrm{a}}$ \\
W21 & $0.99 \pm 0.29^{\mathrm{b}}$ & $2.33 \pm 0.19^{\mathrm{a}}$ & $2.39 \pm 0.27^{\mathrm{a}}$ \\
\hline
\end{tabular}

$a$ and b: Means within the same row within different superscripts for each feeding system are significantly different at $(\mathbf{P}<0.05)$.

\section{Milk composition}

Data is presented in Table 8 recorded the average of milk composition for goats which received PG1 and PG2 compared to PG0. The current study presents that the differences among the PG0, PG1 and PG2 groups was in fat content of goat milk. The fat content was significantly $(\mathrm{P}<0.05)$ higher in does of PG1 and PG2 than those in PG0 ration, but, PG1 and PG2 goats as well as in fat content. Kupczyński et al. (2005) obtained similar higher significant values in fat content use of PG at $250 \mathrm{ml} / \mathrm{h} / \mathrm{d}$, it was $51.28 \mathrm{~g} / \mathrm{l}$ than $34.83 \mathrm{~g} / \mathrm{l}$ in control cows. Similarly, Lien et al. (2010) noticed that cow received PG could be recorded higher fat concentration at 3.62\% than $3.53 \%$ in control group. Energy source of PG could be stimulated the release of fat and it increased milk fat synthesis in the udder (Nogalski et al., 2012). It is possible that the PG supplement extracted an impaired fat release from the adipose tissue, a process that was reflected in the milk fat value variation (Borş et al., 2014). Generally, the reduction of milk fat content is in agreement with the most published work as reviewed by Mecitoğlu et al. (2017) who suggested that reduced milk fat content could be due to: firstly the decrease in plasma non-esterified fatty acids (NEFA) since lowered NEFA concentrations lead to decreased NEFA-uptake by the mammary gland and secondly the lowest proportion of acetate in the rumen which may reduce the amount of acetate available for devolve fatty acid synthesis in the mammary gland. 
Table 8. Effect of feeding PG0, PG1 and PG2 rations on milk composition.

\begin{tabular}{lccc}
\hline Milk & \multicolumn{3}{c}{ Experimental rations } \\
\cline { 2 - 4 } composition\% & PG0 & PG1 & PG2 \\
\hline Fat & $3.50 \pm 0.06^{\mathrm{b}}$ & $4.09 \pm 0.05^{\mathrm{a}}$ & $4.11 \pm 0.05^{\mathrm{a}}$ \\
Protein & $3.08 \pm 0.05$ & $3.18 \pm 0.05$ & $3.19 \pm 0.06$ \\
Lactose & $4.35 \pm 0.04^{\mathrm{b}}$ & $4.67 \pm 0.06^{\mathrm{a}}$ & $4.68 \pm 0.06^{\mathrm{a}}$ \\
SNF & $7.43 \pm 0.09^{\mathrm{b}}$ & $7.86 \pm 0.06^{\mathrm{a}}$ & $7.86 \pm 0.05^{\mathrm{a}}$ \\
TS & $10.93 \pm 0.09^{\mathrm{b}}$ & $11.95 \pm 0.10^{\mathrm{a}}$ & $11.97 \pm 0.10^{\mathrm{a}}$ \\
Acidy & $0.16 \pm 0.07$ & $0.17 \pm 0.06$ & $0.17 \pm 0.05$ \\
pH & $6.51 \pm 0.05$ & $6.58 \pm 0.06$ & $6.66 \pm 0.06$ \\
\hline a and b: Means within the same row within different superscripts for
\end{tabular}

each feeding system are significantly different at $(\mathbf{P}<\mathbf{0 . 0 5})$.

With regard to protein content, the differences among PG0, PG1 and PG2 groups in protein content of goat milk were not significant at lactation period but PG1 and PG2 goats were more in protein content than PG0 goats. From this, Kupczyński et al. (2005) recorded that protein amount in milk cows could show non-significant difference among $500 \mathrm{ml} / \mathrm{d} / \mathrm{h}$ of PG and $0.00 \mathrm{ml} / \mathrm{d} / \mathrm{h}$ of PG , it was117.73-117.78 g/l, respectively. Actually, toward to decrease milk protein content due to decrease of amino acid requirements for gluconeogenesis and thus there would not be a shortage of the spared amino acids for the milk protein synthesis (Toghdory et al., 2009). Also, those authors noticed that protein percentage in cows was 3.00, 3.02, 3.04, 3.03\% when PG supplied at 0, 250, 500 and $750 \mathrm{ml} / \mathrm{h} / \mathrm{d}$, respectively. As well as, Lien et al. (2010) confirmed that an increase in energy content of the feed by adding PG would stimulate an increase in milk protein percentage; hence, they found that protein percentage was up to 3.22- 3.28\% in PG and control cows, respectively.

Concerning to the lactose content, the result showed that lactose content was significantly $(\mathrm{P}<0.05)$ lower in does fed PG0 ration than those fed PG1 and PG2 ration. Hence, feeding PG during lactation has positive effect on content of milk lactose (Kupczyński et al., 2005) revealed that improvement of lactose amount up to 19.13 $\mathrm{g} / \mathrm{l}$ for cows fed PG at $500 \mathrm{ml} \mathrm{h} / \mathrm{d}$ compared to $18.90 \mathrm{~g} / \mathrm{l}$ for control ration. Furthermore, Liu et al. (2009) indicated that higher percentage of lactose up to $4.61,4.64$ and $4.65 \%$ in dairy cow supplied with PG at 150, 300 and 450 $\mathrm{ml} /$ day than $4.58 \%$ in untreated cows, respectively. In contrast to this, Toghdory et al. (2009) found that lactating cows had a tendency to decreased milk lactose percentage with PG supplemented to ration; it was 4.42, 4.34, 4.33 and $4.32 \%$ when rations contained $0,250,500$ and $750 \mathrm{ml}$ of $\mathrm{PG}$, respectively.

Table 8 is showed significant $(\mathrm{P}<0.05)$ differences among the experimental groups in TS and SNF content of goat milk. Actually, the significant values of fat\%, lactose\% may be resulting in TS and SNF content in goats' milk. The general trend of change in the mean total solids of milk during lactation period is in full agreement with those reported by Toghdory et al. (2009). Protein, acidity and $\mathrm{pH}$ values were not affected significantly by dietary treatment at all times of milking periods. Generally, acidity and $\mathrm{pH}$ values showed marked reduction in PG0 compared to PG1 and PG2 goats. Form this, Hussein et al. (2015) found that PG could ameliorate TS, SNF, and acidity up to
14.6, 10.5 and $16.5 \%$ compared to $14.0,9.9$, and $17.0 \%$ in control buffaloes ration, respectively.

\section{Chemical composition of Domiatti cheese}

The results given in Table 9 described the impact of different feeding trial as PG0, PG1 and PG2 in the chemical composition of Domiatti cheese during storage times at 0,30 and 60 days. There were pronounced $(\mathrm{P}<0.05)$ differences among $\mathrm{PG}$ cheese samples and control for TS, FM/DM and TN/DM contents of fresh cheese and during ripening stage. The yield of Domiatti cheese through all treatments was decreased during storage period. A surpass of PG1 and PG2 cheese may be due to the soften curd, which resulted in higher retention of moisture content. Similar trend was found by Ismail and Osman (2004). A higher significant differences $(\mathrm{P}<0.05)$ were found in the total solids (TS \%) than PG0 cheese.

Table 9. Effect of feeding PG0, PG1 and PG2 rations on chemical composition of Domiatti cheese.

\begin{tabular}{lcccc}
\hline Item & $\begin{array}{c}\text { Storage } \\
\text { days }\end{array}$ & \multicolumn{3}{c}{ Experimental rations } \\
\cline { 3 - 5 } ( & 0 & $36.17 \pm 0.44^{\mathrm{b}}$ & $38.00 \pm 0.29^{\mathrm{a}}$ & $38.68 \pm 0.44^{\mathrm{a}}$ \\
Total solid & 30 & $40.63 \pm 0.40^{\mathrm{b}}$ & $45.03 \pm 0.59^{\mathrm{a}}$ & $45.43 \pm 0.26^{\mathrm{a}}$ \\
(TS) & 60 & $41.23 \pm 0.07^{\mathrm{b}}$ & $45.10 \pm 0.16^{\mathrm{a}}$ & $45.53 \pm 0.14^{\mathrm{a}}$ \\
\hline Fat/dry & 0 & $39.60 \pm 0.06$ & $39.72 \pm 0.02$ & $40.60 \pm 0.06$ \\
matter & 30 & $43.95 \pm 0.19^{\mathrm{b}}$ & $45.13 \pm 0.62^{\mathrm{a}}$ & $46.74 \pm 0.55^{\mathrm{a}}$ \\
(FA/DM) & 60 & $43.77 \pm 0.17^{\mathrm{b}}$ & $44.93 \pm 0.28^{\mathrm{a}}$ & $46.61 \pm 0.19^{\mathrm{a}}$ \\
\hline & 0 & $5.88 \pm 0.11$ & $5.91 \pm 0.01$ & $5.98 \pm 0.08$ \\
T.N/DM & 30 & $5.08 \pm 0.05^{\mathrm{b}}$ & $5.35 \pm 0.22^{\mathrm{a}}$ & $5.59 \pm 0.01^{\mathrm{a}}$ \\
& 60 & $5.03 \pm 0.04^{\mathrm{b}}$ & $5.25 \pm 0.22^{\mathrm{ab}}$ & $5.51 \pm 0.01^{\mathrm{a}}$ \\
\hline & 0 & $6.20 \pm 0.05$ & $6.20 \pm 0.02$ & $6.28 \pm 0.06$ \\
$\mathrm{pH}$ & 30 & $4.17 \pm 0.18$ & $4.31 \pm 0.11$ & $4.37 \pm 0.11$ \\
& 60 & $3.90 \pm 0.0$ & $3.91 \pm 0.04$ & $3.95 \pm 0.08$ \\
\hline
\end{tabular}

a and b: Means within the same row within different superscripts for each feeding system are significantly different at $(\mathrm{P}<0.05)$.

Thus, improvement of PG1 and PG2 cheese may be due to the development of acidity which induces shrinkage in the cheese matrix and exudation of moisture from cheese curd. These results are closed with those reported by Hamad and Ismail (2012). Moreover, analysis data in Table 9 explained that the percentages of fat in dry matter (FA /DM \%) increased $(\mathrm{P}<0.05)$ gradually in PG1 and PG2 cheese, but the total nitrogen in dry matter (TN/DM $\%)$ decreased $(\mathrm{P}<0.05)$ in all treatments within advanced of storage period. From this, El-Tahra et al. (2015) found that changing in either FA/DM or TN/DM in cheese might be attributed to the pasture, animal metabolism and amino acid catabolism or microbial activity. The current result could be recorded that there is $(\mathrm{P}>0.05)$ values in $\mathrm{pH}$ values among PG0, PG1 and PG2 during storage time up to 60 days. By advanced storage period from 0 to 60 days, the titratable $\mathrm{pH}$ values decreased from 6.28 to 3.90 in PG0 cheese, from 6.20 to 3.91 in PG2 cheese and from 6.28 to 3.95 in PG2 cheese when cheese stored from 0 up to 60 days, respectively. These results are discussed with those reported by Hamad and Ismail, (2012). On the other hand, Khosrowshahi, et al. (2006) reported that changing in $\mathrm{pH}$ through storage time of cheese may be related to the microbial growth and peptidase activity of lactic acid bacteria and the liberation of amino acids and free fatty acids which stimulate the bacterial activity. 
Organoleptic properties of Domiatti cheese

The organoleptic properties of fresh white cheese treatments using three rations as PG0, PG1 and PG2 during the ripening period formed 0,30 and 60 days are presented in Table 10. As shown, there are no clear differences among PG0, PG1 and PG2 cheese samples in color and appearance values. Then, the scores of color and appearance at the 60 days of ripening stage for treatments PG0, PG1 and PG2 were 14.17, 14.33 and 14.07, respectively. These results are in agreement with those reported by El-Tahra et al. (2015) who revealed that samples of Domiati cheese markedly improved during ripening period while color and appearance scores decreased at the end of ripening period. The body and texture results of cheese samples done from PG0, PG1 and PG2 milk after 60 days of ripening period were 32.33, 33.90 and 33.60, respectively. In addition, the flavour scores of treatments milk from PG0, PG1 and PG2 after storage up to 60 days as maturation period were 39.00 , 40.67 and 40.67, respectively. Hence, flavor is the sensation produced by a material taken in the mouth, perceived principally by the senses of taste and smell, and also by the general pain, tactile, and temperature receptors in the mouth (Hamad and Ismail, 2012). Flavor also denotes the sum of the characteristics of the material which produces that sensation (El-Tahra et al., 2015).

Table 10. Effect of feeding PG0, PG1 and PG2 rations on organoleptically properties of Domiatti cheese.

\begin{tabular}{|c|c|c|c|c|c|}
\hline \multirow{2}{*}{$\begin{array}{l}\begin{array}{l}\text { Storage time } \\
\text { (days) }\end{array} \\
\end{array}$} & \multirow{2}{*}{ Proprieties } & \multirow{2}{*}{$\begin{array}{c}\text { Score of } \\
\text { test }\end{array}$} & \multicolumn{3}{|c|}{ Experimental rations } \\
\hline & & & PG0 & PG1 & PG2 \\
\hline \multirow{7}{*}{ Zero } & Color and & 15 & $13.50 \pm$ & $14.33 \pm$ & $14.50 \pm$ \\
\hline & appearance & 15 & 0.29 & 0.28 & 0.44 \\
\hline & Body and & 35 & $29.50 \pm$ & $32.33 \pm$ & $32.67 \pm$ \\
\hline & & & 0.28 & 1.02 & 0.177 \\
\hline & Flavour & 50 & $36.83 \pm$ & $37.50 \pm$ & $37.60 \pm$ \\
\hline & & & 0.44 & 0.104 & 0.59 \\
\hline & Total & 100 & $\begin{array}{l}79.83 \pm \\
156^{\mathrm{b}}\end{array}$ & $84.16 \pm$ & $\begin{array}{r}84.77 \pm \\
212^{\mathrm{a}}\end{array}$ \\
\hline \multirow{7}{*}{30} & $\mathrm{Col}$ & & $14.00 \pm$ & $14.33 \pm$ & $14.50 \pm$ \\
\hline & appearance & 15 & 0.28 & 0.16 & 0.10 \\
\hline & Body and & 35 & $31.77 \pm$ & $33.17 \pm$ & $33.33 \pm$ \\
\hline & texture & 35 & 0.96 & 0.60 & 0.44 \\
\hline & Flay & 50 & $37.83 \pm$ & $39.10 \pm$ & $39.17 \pm$ \\
\hline & Tiavuu & 30 & 0.44 & 1.01 & 0.97 \\
\hline & Total & 100 & $\begin{array}{c}83.60 \pm \\
1.68^{\mathrm{b}}\end{array}$ & $\begin{array}{c}86.60 \pm \\
2.01^{\mathrm{ab}}\end{array}$ & $\begin{array}{c}87.00 \pm \\
1.32^{\mathrm{a}}\end{array}$ \\
\hline \multirow{7}{*}{60} & Color and & & $14.17 \pm$ & $14.33 \pm$ & $14.07 \pm$ \\
\hline & appearance & 15 & 0.33 & 0.44 & 0.23 \\
\hline & Body and & 35 & $32.33 \pm$ & $33.90 \pm$ & $33.60 \pm$ \\
\hline & 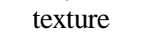 & 35 & 0.44 & 0.35 & 0.55 \\
\hline & Flavour & 50 & $39.00 \pm$ & $40.67 \pm$ & $40.67 \pm$ \\
\hline & & & 1.00 & 2.36 & 1.89 \\
\hline & Total & 100 & $\begin{array}{c}85.50 \pm \\
211^{\mathrm{b}}\end{array}$ & $\begin{array}{l}88.90 \pm \\
254^{\mathrm{ab}}\end{array}$ & $\begin{array}{c}88.34 \pm \\
261^{\mathrm{a}}\end{array}$ \\
\hline
\end{tabular}

$a$ and b: Means within the same row within different superscripts for each feeding system are significantly different at $(\mathbf{P}<0.05)$.

Latest authors confirmed that flavors increased during ripening period. Improving in organoleptic characteristics of domiatti cheese may be attributed to different aroma which came from propylene glycol (PG) which used in feeding dairy goats. Elgersma et al. (2006) explained that forage may affect the organoleptic characteristics of cheese. Generally, in all cheese treatments, the sensory evaluation scores gradually increased during ripening period. Thus, the total scores of organoleptic properties of samples PG1 and PG2 at the beginning of ripening period at zero day up to 60 days observed the highest $(\mathrm{P}<0.05)$ significant values compared to cheese samples obtained from PG0 milk.

\section{CONCLUSION}

The present results indicate that the PG can be used as an effective glucogenic precursor to improve the metabolic status of transition dairy goats. The PG supplementation in dairy goat diet was beneficial to improve digestion coefficient, nutritive values, milk yield, milk composition and milk manufacturing as Domiatti cheese. The dosage of PG at 10 or $20 \mathrm{~g} /$ day/ head under the present experimental conditions was suggested as safety dosage without any negative effects occurred among the tested animals.

\section{REFERENCES}

Abdel-Latif, M.A., E. S. EL-Gohary, A. A. Gabr., A.F. ElHawary, S. A. Ahmed, S. A. Ebrahim and M. M. Fathala (2016). Impact of supplementing propylene glycol and calcium propionate to primiparous buffalo cows during the late gestation and early lactation period on reproductive performance and metabolic parameters. Alexandria Journal of Veterinary Sciences, 51 (1): 114-121.

Akamatsu, H., H. Uruma, T. Seto, M. Hurumoto, K. Nakashima, Y. Shinozuka and K. Kawai (2018). Preventative effect of oral administration of propylene glycol and bypass amino acids on the development of ketosis in dairy cows. Asian Journal of Animal and Veterinary Advances, 13 (1): 91-95.

Alipour, D. and Y. Rouzbehan (2007).Effects of ensiling grape pomace and addition of polyethylene glycol on in vitro gas production and microbial biomass yield. Animal Feed Science and Technology, 137 (1-2):138-149.

Al-Masri, M. R. (2016). In vitro rumen fermentation kinetics and nutritional evaluation of olive tree (Olea europaea L.) pruning residues as affected by cutting regimen. Livestock Research for Rural Development, 28 (8): 149-155.

AOAC (2007). Association of Official Analytical Chemists. Official Methods of Analysis. 19 Edition. Washington, DC: AOAC. USA.

Azza, G. M. Ayoub, Magda, M. M. Sabah, and Amal, I. El-Shorbagi (2015). Effect of propylene glycol supplementation to feed of dairy cows on some biochemical measurements. Egypt Journal Chemistry Environmental Health, 1 (1):899-913.

Ben Salem, H., Imène Ben Salem and M.S. Ben Said (2005). Effect of the level and frequency of PEG supply on intake, digestion, biochemical and clinical parameters by goats given kermes oak (Quercus coccifera L.) -based diets. Small Ruminant Research, 56: 127-137. 
Besharati, M. and A. Taghizadeh (2011). Effect of tannin-binding agents (polyethylene glycol and polyvinylpyrrolidone) supplementation on in vitro gas production kinetics of some grape yield byproducts. International Scholarly Research Notices Veterinary Science, 1-8.

Borş, S. I., G. Solcan and A. Vlad-Sabie (2014). Effects of propylene glycol supplementation on blood indicators of hepatic function, body condition score, milk fat protein concentration and reproductive performance of dairy cows. Acta Veterinaria Brno, 83: 27-32.

Conway, E. G. and M. S. O'Malley (1957). Microdiffusion Analysis and Volumetric Error. $4^{\text {th }}$ Ed. O. Grasphy-Lock wood and Sons Ltd., London.

Cruz, W. F. G., G. L. Macedo Junior, M. E. B. Andrade, E. B. Shultz and V. J. C. Rodrigues and S. P. Silva (2014). Consumo, digestibilidade e parâmetros fisiológicos de ovelhas suplementadas com níveis crescentes de propilenoglicol na água. Veterinária Notícias, 20 (1): 19-27.

Elgersma, A., S. Tamminga and G. Ellen (2006). Modifying milk composition through forage. Animal Feed Science and Technology, 131: 207225.

El-Tahra, M. A. Ammar, M. M. Ismail and R. I. ElMetwally (2015). Effect of adding smoke liquid or powder to goat's milk on some characteristics of domiatti cheese. American Journal of Food Science and Nutrition Research. 2 (2):47-56.

Erwin, E., G., Marco and E. Emery (1961). Volatile fatty acid analysis of blood and rumen fluid by gas chromatography. Journal Dairy Science, 44, 17681771.

Ferraro, S. M., G.D. Mendoza, L.A. Miranda and C.G. Gutiérrez (2016). In vitro ruminal fermentation of glycerol, propylene glycol and molasses combined with forages and their effect on glucose and insulin blood plasma concentrations after an oral drench in sheep. Animal Feed Science and Technology, 213: 74-80.

Formigoni, A. M., C. Cornil, A. Prandi, A. Mordenti, A. Rossi, D. Portetelle, and R. Renaville (1996). Effect of propylene glycol supplementation around parturition on milk yield, reproduction performance and some hormonal and metabolic characteristics in dairy cows. Journal Dairy Research, 63: 11-24.

Franzolin, R. and Burk A. Dehority (2010). The role of $\mathrm{pH}$ on the survival of rumen protozoa in steers. Revista Brasileira de Zootecnia, 39 (10): 22622267.

Gavan, C. and V. Motorga (2009). The effects of oral administration of propylene glycol and calcium propionate in dairy cows. Zootehnie şi Biotechnologii, 42 (2): 255-260.

Gowda, A. J. S., M. Devaraj and A. Krishnaswamy (2013). The influence of feeding propylene glycol, rumen protected- fat and protein on milk yield in early lactating cows. International Journal of Science and Research, 4 (7): 1254-1257.
Hilton, J. W., J. L., Atkinson and S. J. Slinger, (1986). Effect of propylene glycol on feed digestibility and the growth and physiological response of rainbow trout. Canadian Journal of Animal Science, 66: 1057-1063.

Hussein, H. A., S. M. Abdel-Raheem, M. Abd-Allah and W. Senosy (2015). Effects of propylene glycol on the metabolic status and milk production of dairy buffaloes. Tierärztliche Praxis Großtiere, 43 (G): 110.

Ismail, M. M. and M. M. Osman (2004). Effect of adding some herbs to goat feed on chemical, microbiological and organoleptic properties of Domiati cheese. Journal Agriculture. Science Mansoura Univiersity, 29 (1): 253-263.

Khosrowshahi, A., A. Madadlon, E. Zadah, M. Mousavi and Z. Emam-Djomeh (2006). Monitoring the chemical and textural changes during ripening of Iranian white cheese made with different concentration of starter. Journal Dairy Science, 62: (supp. 1): 59.

Kristensen, N. B. and B. M. Raun (2007). Ruminal and intermediary metabolism of propylene glycol in lactating Holstein cows. Journal Dairy Science, 90 (10): 4707-4717.

Kupczyński, R., M. Adamski and G. Chládek (2005). The influence of propylene glycol on body condition and milk yield of cows as well as colostrum and milk composition. Acta Universitatis Agriculture Et Silviculturae Mendelianae Brunensis, III (4): 51-60.

Lien, T. F., L. B. Chang, Y. M. Horng and C. P. Wu (2010). Effects of propylene glycol on milk production, serum metabolites and reproductive performance during the transition period of dairy cows. Asian-Australian Journal Animal Science, 23 (3): 372-378.

Ling, E. R. (1963). A Text Book of Dairy Chemistry. Vol 2. $3^{\text {rd }}$ ed., Champon and Hall, London.

Liu, Q., C. Wang, W. Z. Yang, W. W. Zhang, X. M. Yang, D. C. He, K. H. Dong1 and Y. X. Huang (2009). Effects of feeding propylene glycol on dry matter intake, lactation performance, energy balance and blood metabolites in early lactation dairy cows. Animal, 3 (10): 1420-1427.

Lomander, H., J. Frössling, K. L. Ingvartsen, H. Gustafsson, and C. Svensson (2012) Supplemental feeding with glycerol or propylene glycol of dairy cows in early lactation-Effects on metabolic status, body condition, and milk yield. Journal Dairy Science, 95: 2397-2408.

Madibela, O. R., O. Seitshiro and M. E. Mochankana (2006). Deactivation effects of polyethylene glycol (peg) on in vitro dry matter digestibility of Colophospermum mopane (Mophane) and Acacia browse trees in Botswana. Pakistan Journal of Nutrition, 5 (4): 343-347.

Mecitoğlu, Z., Ç. K. Sevim, M. L. Özdüven, M. Özder and E. Kennerman (2017). Effects of prepartum treatment with monensin or propylene glycol mixed with concentrate on milk yield and blood NEFA and BHBA levels in dairy cows. Turkish Journal of Veterinary and Animal Sciences, 41: 667-671. 
Melendeza, P., K., Severinob, M. Paz Marinb and M. Duchens (2018). The effect of a product with three gluconeogenic precursors during the transition period on blood metabolites and milk yield in Chilean Holstein cattle. Journal of Applied Animal Research, 46 (1): 613-617.

Metzger, L., D. Barbano, M. Rudan, and P. Kindstedt. (2000). Effect of milk preacidification on low fat Mozzarella cheese. I. Composition and yield. Journal of Dairy Science, 83 (4): 648-658.

Nalawade, T. M., K. Bhat and S. H. P. Sogi (2015). Bactericidal activity of propylene glycol, glycerin, polyethylene glycol 400, and polyethylene glycol 1000 against selected microorganisms. Journal of International Society of Preventive \& Community Dentistry, 5: 114-119.

Nelson, J. A. and G. M. Trout (1965). Judging dairy products Judging dairy products. (4th edition). Phelan, J., J. Renaud, and P. Fox. 1993. Some nonEuropean cheese varieties. Pages 421-465 in Cheese.

Nogalski, Z., M. Wroński, B. Lewandowska and P. Pogorzelska (2012). Changes in the blood indicators and body condition of high yielding Holstein cows with retained placenta and ketosis. Acta Veterinaria Brno, 81: 359-364.

NRC (2007). Nutrient requirements of small ruminants: Sheep, goats, cervids, and new world camelids, National Academies Press, Washington, D.C., U.S.A.

Pechová, A., P. Pečínka, J. Kudrnáčová and L. Pavlata (2014).The comparison of propylene glycol and glycerol as feed additives in early lactation of high producing dairy cows. Journal of Animal and Feed Sciences, 23 (4): 285-292.

Rinne M., S. Jaakkola and P. Huhtanen (1997). Grass maturity effects on cattle fed silage-based diets. 1 . Organic matter digestion, rumen fermentation and nitrogen utilization. Animal Feed Science Technology, 67: 1-17.
Rukkwamsuk, T. and S. Panneum (2010). Effect of oral administration of propylene glycol during periparturient period on blood biochemical parameters and liver triacylglycerol accumulation in post-parturient dairy cows. African Journal of Agricultural Research, 5 (23): 3239-3245.

Santos, R. P., G. L. M Junior, S. P. Silva, L. F.Sousa and M. E. B. Andrade (2017). Inclusion of propylene glycol in the diet of sheep and its effect on their lambs' protein and mineral metabolites. Acta Scientiarum Animal Sciences, 39 (3): 297-302.

Shankare Gowda, A. J., M. Devaraj and A. Krishnaswamy (2013). The influence of feeding propylene glycol, rumen protected- fat and protein on milk yield in early lactating cows. International Journal of Science and Research, 4 (7): 1254-1257.

SPSS (2013). Statistical package for social sciences, IBM ${ }^{\circledR S P S S}$ Statistics Data Editor 22.0 License Authorization Wizard, Chicago, USA.

Toghdory, A., N. Torbatinejad, R. Kamali, M. Mohajer and M. Chamani (2009). Effects of propylene glycol powder on productive performance of lactating cows. Pakistan Journal of Biological Sciences, 12: 924-928.

Van Soest, P. J. and J. B. Robertson (1985). Analysis of forages and fibrous feeds. A laboratory manual for animal science, Vol. 613. Cornell University, Ithaca, New York.

Van Soest, P. J., J. B. Robertson and B. A. Lewis (1991). Methods for dietary fiber, neutral detergent fiber, and no starch polysaccharides in relation to animal nutrition. Journal Dairy Science, 74: 3583-3597.

Warner, A. C. I. (1964). Production of volatile fatty acid in the rumen, methods of measurements. Nutrition Abstracts and Reviews Series B, 34: 339.

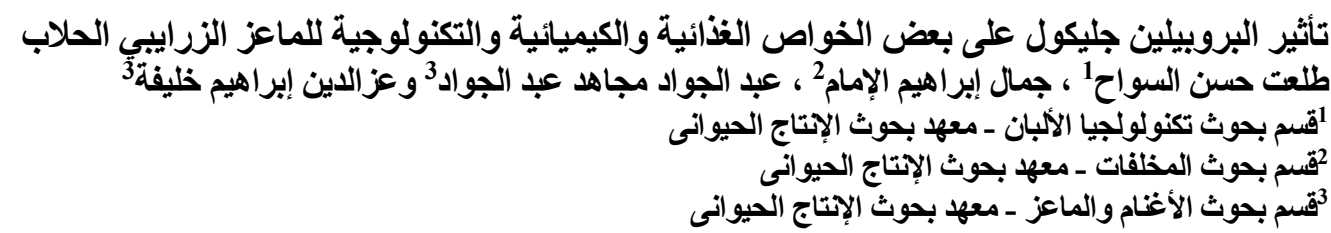

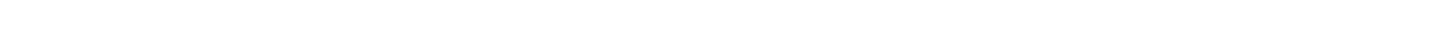

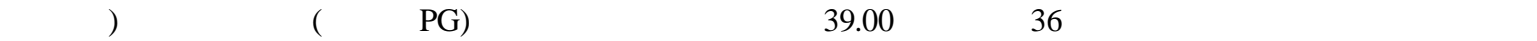

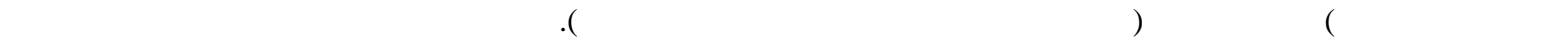

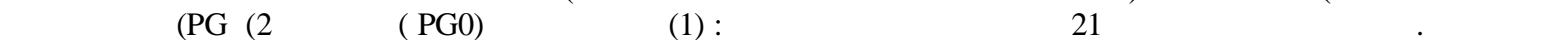

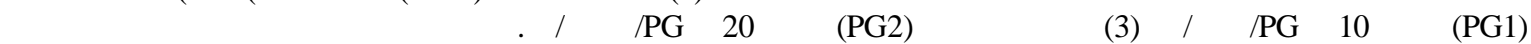

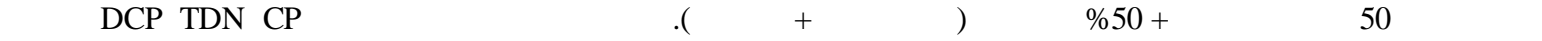

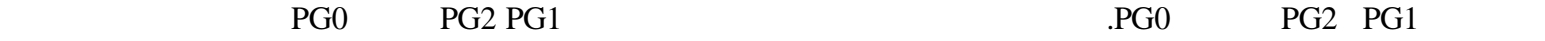

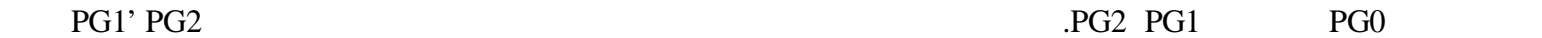

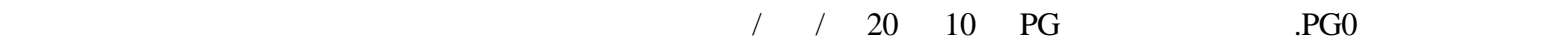

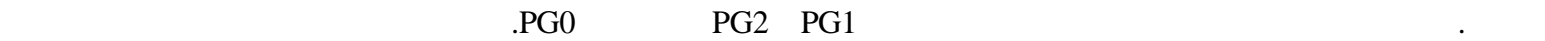

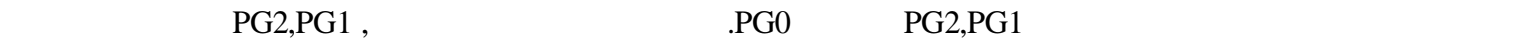

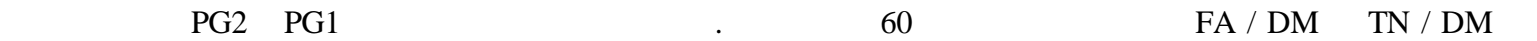

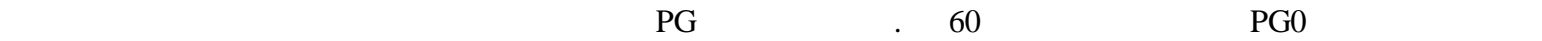

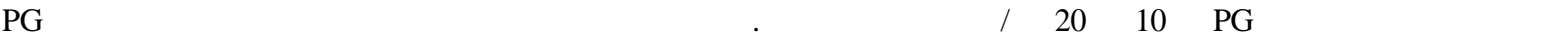

